Conference

\section{Circuit}

\title{
Education for the
} 21 st cenfury

\author{
By Janis L. Dickens
}

\section{Models, management, and money: The spring meeting of CCUMC}

$\mathbf{T}$ he spring meeting of the Consortium of College and University Media Centers (CCUMC), April 11-14, focused on updates in several areas of interest to library and media specialists. The conference was hosted by Point Loma Nazarene College in San Diego and included tours of facilities at the University of California-San Diego and California State University-San Diego.

\section{Keeping up with rapid change}

Keynote speaker Lynn Milet (Lehigh University) presented "Organizational Models for Managing Technology Services: Keeping Up with Rapid Change." Libraries, media centers, and computing operations are in a period of reorganization and change at colleges and universities across the country. According to Milet, "We can succeed in each of these changes if we position ourselves as strategic partners by cooperating and collaborating with other areas; by enriching customers by providing them with valued services; by organizing ourselves and our areas to master change; and by leveraging our human resources."

\section{The use of multimedia in education}

A Copyright Multimedia Guidelines update was provided by Lisa Livingston, who said that the Fair Access Working Committee charged with developing these guidelines had met five times since the annual conference in October and reported significant developments. She distributed a draft dated March 28, 1996, for discussion. Many organizations are cooperating and partnering in the process and production of the final document. A teleconference update is planned when the guidelines are final as this is a topic of broad interest across the country.

\section{CD-ROM vs. the Internet}

Rebecca Butler and Catherine Cunningham (East Tennessee State University) presented "The Tortoise and the Hare of CD-ROMs vs. the Internet," in which they gave comparisons, advantages, and disadvantages of educational and research applications of using $C D-R O M$ versus using the Internet. In the end, they pointed out that the two are best used for different purposes; both have strengths and weaknesses depending on the need.

\section{Constructing a Web service}

Ray Schwartz (Rutgers University) presented "Constructing a Web Service for Your Department." Schwartz motivated the audience by introducing potential advantages of the Web in the library/media center and by showing a few examples. He spoke about the importance of presentation and design of the pages, as well as logic and organization. He cautioned us on the expectations and hopes of viewers that the institution is buying into a regular update and maintenance of its pages. He spoke about the advisability and possibility of using forms via the Web, and shared with us an excellent bibliography. He recommended seeking more information at http://newark.rutgers.edu/ rps/ constructing.html.

\section{Faculty development}

Martha Gilliland, J. Timothy Kolosick, and Karen Smith (University of Arizona) presented "The Student, the Learner and the Obsolescent Professor: Changing Roles with Technology." The University of Arizona's approach to faculty development may be unique in the country. The 
process has three components: 1) leadership develops a set of guiding principles; 2) faculty participate in dialogues about these principles, deciding on projects that, from their frame of reference, are key to progress; and 3) leadership makes certain that these projects are allowed to develop, transferring accountability for the results to the faculty themselves. Thus the role of leadership is 1) to set the vision or the guiding principles, and 2) to make certain that the projects the facuity want to realize can, in fact, happen. This process is empowering to the faculty, highly creative, and it puts accountability into the faculty's hands. This approach is also somewhat chaotic, with no fixed organizational structure; rather the structure is fluid, relying completely on relationships and teams that form around projects. The result is a powerful engagement of people from all aspects of the institution and a very high level of creativity. The excellence that is achieved is both different from and better than what has previously been achieved through a more traditional topdown management process.

\section{Smart classrooms}

Details about the facility toured the day before were given by Janet Bedford and David Sharpe (San Diego State University) in "Smart Classrooms with Multi-Media Integration." They reported that Instructional Technology Services on their campus has equipped two large lecture halls with the latest in presentation technology: a video/data projection system; a sound amplification system with wired and wireless microphones; a Mac/PC computer system with CD-ROM, removable hard drive, computer video interface, ethernet card, and appropriate installed software; a videodisk player; a video recorder; and a visual presenter, all located in a secure classroom instructor station. Bedford and Sharpe presented an overview as well as exact design and equipment specifications, complete with photos and demonstrations.

\section{TREES On campus}

Kevin Robinson and Eric Frost (faculty in geological sciences at San Diego State University) spoke about "Using the World Wide Web As Part of an Active Learning Environment for Preservice Elementary Teachers." TREES (Teaching Resources for Education in Earth Science) is the primary Web organizational tool for teaching this material (http://earthview.sdsu. edu/trees/trees.html). TREES provides curricu- lum materials, innovative methodologies, and pertinent links for earth science education. It was developed to enhance instruction and to facilitate the use of the Web as a tool for the development of the earth science curriculum. Preservice and inservice teachers can truly benefit from the type of instructional support the Web provides, but the Internet can be overwhelming to them. TREES provides a convenient shopping place for teachers and students who want to build or experience meaningful earth science curricula.

\section{The master's track}

Art Battson (University of California, Santa Barbara) spoke about "The Master's Track: Electronics and the Bright Future of Education." He explained that the master's track is based on the safe assumption that 10 to 20 percent of high school juniors and seniors are fully capable of mastering college-level material. Given access to the material, they ought to be able to complete their lower-division requirements prior to the time they would ordinarily graduate from high school. Having done so, they would be on track to complete a master's degree in less time than most students today complete a bachelor's degree. One of Battson's most visual analogies was comparing the education system to prison. The main difference, he explained, is that prisons often release their inmates early for good behavior. Schools, on the other hand, typically confine their students for the full duration of their term. He presented many advantages of the program, both intellectual and economic.

\section{Revitalizing the infrastructure}

Ann Shore (Florida State University) presented "Planning for Technology Integration in Higher Education." Her thesis was that the general consensus among educators, policymakers, administrators, and the public is that the current teaching infrastructure must be revitalized and reengineered to reach the primary educational goals of increased access, improved quality, and reduced cost. Not only are we looking at the way students learn, but also at changes in where and how students learn and in how instructors teach. The broad spectrum of approaches to instructional uses of computers ranges from enhancing traditional teaching techniques to supporting entirely new modes of learning. Learning no longer need be confined to the (CCUMC cont. on page 455) 


\section{Important Resourees for Akademic Libraries}

\section{Managing Change in Academic Libraries}

\section{Edited by Joseph J. Branin}

This new book helps academic librarians plan, implement, and manage changes to the fundamental structure of their organizations, It explores how academic librarians can respond imaginatively and nimbly to economic, political, and technological change that is enveloping their professional work. The chapters represent a mixture of radical and rational approaches to managing change, with each chapter giving a particular academic librarian's views.

(A monograph published simultaneously as the Journal of Library Administration, Vol. 22, Nos. 2/3.) $\$ 29.95$ hard. ISBN: 1-56024-810-6.

Text price (5+ copies): $\$ 19.95$.

1996. Available now, Approx. 172 pp. with Index.

\section{Librarians on the Internet}

\section{Impact on Reference Services \\ Edited by Robin Kinder, MLS}

"A GROUNDBREAKING BOOK with contributions from practicing librarians. This publication, which includes a detailed index, represents an occurate view of the impact of the Internet on reference services, It pulls together a variety of articles on a timely topic. Any librarian with an interest in the Internet will find this thought-provoking. It is recommended for library and information science libraries:"

\section{-Special Libraries}

(A monograph published simultaneously as

The Reference Librarian, Nos. 41/42)

$\$ 69.95$ hard. ISBN: 1-56024-672-3.

Text price ( $5+$ copies): $\$ 24.95$.

1994. $410 \mathrm{pp}$, with Index

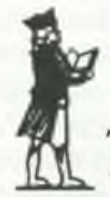

The Haworth Press. Inc.

10 Allice Street, Binghamton, NY 13904
Gareer Planning and Job Searching in the Information Age

\section{Edited by Elizabeth A. Lorenzen, MLS}

This new book answers key questions for today's providers of career-planning and jobsearching information. Librarians and career development professionals' concerns such as cost-effective use of the Internet, the reliability and integrity of electronic resources, and successful search strategies are addressed in this comprehensive collection. It presents a broad base of knowledge from which readers are launched into tightly focused case studies.

(A monograph published simultaneously as

The Reference Librarian. No. 55.)

\$29.95 hard. ISBN: 1-56024-838-6.

Text price (\$+ copies): $\$ 19.95$.

Available Summer 1996. Approx. 136 pp.

\section{Lihrary Services for Gareer Planning, Joh Searching and Employment Opportunities}

Edited by Byron Anderson, MA, MLS "THIS UP-TO-DATE AND TIMELY BOOK ADDS SIGNIFICANTLYTOTHE UTERATURE ON CAREER SERVICES AND MATERIALS IN UIBRARIES. It covers topics on which little has been previously published, i.e., training librarians for library career centers, evaluoting audiovisual moterials, and selecting job search resources for people with disobilities."

-Kathleen M. Savage, MLS, Editor. Professional Careers Sourcebook (Gale 1992), and Vocotional Coreers Sourcebook (Gale 1992)

(A monograph published simultaneously as

The Reference Librarian, No. 36.)

\$49.95 hard. ISBN: 1-56024-303-1.

\$19.95 soft. ISBN: 0-7890-0054-7.

1992.183 pp. Reprinted in paperback 1996. Available now. 
Collections Department of the University of Colorado at Boulder Libraries. Donated by Josiah Lee Auspitz, the collection augments the library's holdings of German-language Viennese Revolution materials that document the rapidly unfolding events of the full length of the revolutionary period up to the aftermath of the capitulation of the revolutionary forces.

\section{The papers of the Franco-Russian nov-} elist and revolutionary Victor Serge (1890-1947) have been acquired from his son, the painter Vlady Kibalchich, by the Beinecke Rare Book \& Manuscript Library at Yale University. Serge was a Russian Bolshevik whose life and activities spanned some of the most tumultuous years of the century in Russian and European politics. He was an organizer of the Communist International, setting up the Comintern publishing house and print shop and editing Imprekorr, the Comintern press service in Berlin and Vienna. He was later expelled from the Party, imprisoned in Central Asia, and then ex- iled, first to Europe and finally to Mexico. The acquisition includes Serge's research files and drafts of articles, largely from periods of his life spent in Marseilles and Mexico (1940-47), as well as manuscripts from some of his many books. The archive also includes unpublished drafts, photographs, clippings, and correspondence with such figures as Leon Trotsky, André Gide, George Orwell, and Dwight MacDonald.

\section{The Rhombus Media film archive, certi}

fied as nationally significant by the Cultural Property Review Board, has been acquired by the York University Archives and Special Collections in Toronto. Rhombus Media was formed in 1979 by three York University film students and produced more than 50 critically acclaimed films. The collection comprises 40 titles, 34 hours of finished film, plus 720 hours of raw film and videotape, as well as all production materials for the recent world-renowned production Thirty Two Short Films About Glenn Gould.

\section{(CCUMC cont. from page 440)}

classroom or lecture hall. Distance education systems integrating computers, video, and telecommunication technologies can carry advanced and specialized courses beyond the campus to remote and nearby sites. Communication tools and computing create electronically linked, global communities. New visualization tools provide learning experiences in interactive, virtual environments. The proponents of educational reform believe that the time is right to make the transition from a teacher-centered environment to a learner-centered one because of the vast amount of change required in higher education. Instructional technology as a tool is viewed as a means of supporting the educational goals of the new teaching infrastructure.

\section{Keeping all the balls in the air}

Two final presentations were very popular. Bernard Colo's (Simmons College) "Juggling 101, Keeping All the Balls in the Air: Designing and Building Classrooms of the 21st Century: A Case Study" described Simmons' four-month renovation of three major campus classrooms and the constraints and environments involved, including the needs of a faculty of diverse teaching styles, incorporating multimedia and computing capabilities, deciding what equipment should be included, incorporating ADA guide- lines, and following through with the design and installation.

\section{Catalogs on the Web}

Finally, Peter Mason presented "WWW Access to Your Catalog: Techniques and Pitfalls" in which he focused on the use of Medianet to make your media catalog accessible through your Web homepage. He demonstrated Medianet's capability to access your online public access catalog through a Web homepage, maintaining your catalog on the Web, creating mediagraphies, and automatic updating. He demonstrated exporting the data and creating the header, title list, html trailer, order form, detail description file, contact info, detailed annotations, and a mediagraphy list. He encouraged the audience to access http:// www.dymaxion.ns.ca/medianet and click on OPAC options for a demonstration.

\section{A useful conference}

The conference provided a time of intellectual stimulation, rich networking opportunities, and wonderful amenities. The next conference of CCUMC will be October 17-21, 1996, hosted by the University of Kansas, Lawrence. For more information contact Don Rieck, executive director, CCUMC, (515) 294-8022. 